\title{
Increased Insulin-like Growth Factor 1 Activity Can Rescue KLE Endometrial-like Cells from Apoptosis
}

\author{
Michael Koutsilieris, ${ }^{1}$ George Mastrogamvrakis, ${ }^{1}$ Panayiotis Lembessis, ${ }^{1,2}$ Antigone Sourla, \\ Spyros Miligos ${ }^{3}$ and Stelios Michalas ${ }^{3}$ \\ ${ }^{1}$ Department of Experimental Physiology, Medical School, University of Athens, Goudi, Athens Greece \\ ${ }^{2}$ Endo/OncoResearch Laboratories; Platia Mavili, Ampelokipi, Athens Greece \\ ${ }^{3}$ Department of Obstetrics-Gynecology, Medical School, University of Athens, Athens, Goudi Greece
}

Accepted September 15, 2000.

\begin{abstract}
Background: The peritoneal fluid (PF) of women with endometriosis contains protease(s) activity able to hydrolyze insulin-like growth factor-binding protein 3 (IGFBP-3), increasing the bioavailability of insulin-like growth factor1 (IGF-1) locally. Therefore, we characterized the effects of IGF-1 on KLE endometrial-like cells in vitro.

Materials and Methods: The mitogenic effect of IGF-1 was assessed by the analysis of the DNA content and cell count. Apoptosis was triggered experimentally by the $48 \mathrm{hr}$ exposure of KLE cells to $100 \mathrm{nM}$ of adriamycin in the presence and absence of IGF-1 $(50 \mathrm{ng} / \mathrm{ml})$. Adriamycin apoptosis of KLE cells was determined by the number of
\end{abstract}

dead KLE cells using trypan blue exclusion and by the DNA fragmentation on simple agarose gel and flow cytometry of propidium iodide and HOECHST 33342stained KLE cells using an EPICS 753 pulse cytometer. Results: IGF-1 stimulated the growth of KLE cells in a dose-dependent manner (optimal dose of $50 \mathrm{ng} / \mathrm{ml}$ ) and protected KLE cells from adriamycin (100 nM)-induced apoptosis.

Conclusions: These data suggest that IGF- 1 is a survival factor for KLE cells. Conceivably, increased IGF-1 activity in the PF can optimize both the survival and ectopic growth of endometrial cells in the peritoneal cavity.

\section{Introduction}

Endometriosis is defined as the ectopic growth of endometrial-like tissue on the peritoneum and the organs of the pelvic cavity (1). The pathogenesis of endometriosis may be associated with the phenomenon of retrograde menstruation; whereas, the ectopic growth of endometrial-like tissue is dependent upon sex steroid hormones and local growth factors, such as insulin-like growth factor 1 (IGF-1) $(2,3)$.

Recent studies documented that peritoneal fluid (PF) of women with and without laparoscopic evidence of endometriosis contained growth factor activity for endometrial-like cells, which is, at least in part, associated with the production of $\mathrm{N}$-terminal proteolytic fragments of IGF-binding protein 3 (IGFBP-3) $(4,5)$. These $\mathrm{N}$-terminal truncated forms of IGFBP-3 contained significant mitogenic activity for endometrial-like cells in vitro (5). In addition, when the PF of women with endometriosis were analyzed by isoelectric focusing, the N-terminal truncated forms of IGFBP-3 co-eluted with urokinase-type

Address correspondence and reprints requests to: Michael Koutsilieris, MD, Ph.D, Department of Experimental Physiology, Medical School, University of Athens, Goudi-Athens 115 27, Greece. Phone: 301-7711222; Fax: 301-7774902; E-mail: mkouts@medscape.com plasminogen activator (UPA), a serine protease capable of hydrolyzing IGFBP-3, thereby, increasing IGF-1 bioavailability locally (6).

Notably, uPA is known to have a pivotal role in regulating the activity of other matrix proteases $(7,8)$ and several growth substances, such as the IGFs in the extracellular matrix, circulation, and other body fluids, including PF (9-13). Recently, our laboratory documented that the exogenous administration of IGF-1 and endogenous increase of IGF- 1 bioavailability produced by the uPA-mediated-limited hydrolysis of IGFBPs, rescued breast and prostate cancer cells from programmed cell death in vitro (14-16). In addition, anti-IGF-1 therapy reintroduced an objective clinical response to androgen ablation therapy of prostate cancer patients who had progressed to the hormone refractory stage of the disease (17). These data indicated that exogenous IGF- 1 and/or endogenously increased IGF-1 bioavailability in host tissues can exert a novel survival factor activity, rescuing metastatic cancer cells from apoptosis in vitro (18).

Since the pathophysiology of endometriosis may include the transplantation of endometrial-like cells in the peritoneal cavity, it is conceivable that a survival mechanism could participate in the pathogenesis of endometriosis (19). This survival mechanism could enable endometrial-like cells, reaching the 
peritoneal cavity by retrograde menstruation, first to survive, and then to grow and develop the endometriotic tissue on the peritoneum and the organs of peritoneal cavity (20).

Therefore, we assessed whether exogenous IGF-1, apart from being a growth factor, can optimize the survival of KLE endometrial-like cells in vitro. Indeed, IGF-1 stimulated the growth and protected KLE endometrial-like cells from adriamycin-apoptosis in vitro. Therefore, it is possible that an increased IGF- 1 activity in the PF of women with endometriosis can optimize both the survival and growth of ectopic endometrial-like tissue.

\section{Material and Methods Cell Cultures}

KLE endometrial-like cells were characterized in our laboratory previously when we studied their response to growth factors (including IGF-I) and peritoneal fluid mitogens in parallel experiments using the primary cultures of epithelial cells enzymatically prepared from biopsies of endometrial tissue and endometriotic lesions as control $(4,5)$. KLE cells were grown in $75-\mathrm{cm}^{2}$ culture flasks using Dulbecco's modified Eagle's medium/F-12 (DMEM/F-12, GIBCO/ BRL, Gaithersburg, MD) containing 5\% calf serum (CS). The KLE cells were plated at a cell density of 15,000 cells in 24-well plates and grown for $48 \mathrm{hr}$ with DMEM/F-12 medium containing $0.5-5 \%$ CS, depending on the experiment. After $48 \mathrm{hr}$ incubation, the culture media were changed with media containing 5\% CS and increasing concentrations (1-100 $\mathrm{ng} / \mathrm{ml}$ ) of recombinant human IGF-1 (R\&D Systems) or two different concentrations (100 nM and $5 \mu \mathrm{M})$ of adriamycin (Sigma) were added. In addition, experiments assessing the combined effect of adriamycin $(100 \mathrm{nM})$ plus IGF-1 $(50 \mathrm{ng} / \mathrm{ml})$ were performed.

\section{Cytotoxicity Assays}

The number of alive and dead KLE cells was assessed by trypan blue exclusion after their exposure to $100 \mathrm{nM}$ and $5 \mu \mathrm{M}$ adriamycin for $48 \mathrm{hr}$. The KLE cells were plated at 15,000 cells/well and cultured with media supplemented with $0.5 \%, 2.5 \%$, and $5 \%$ CS plus $100 \mathrm{nM}$ or $5 \mu \mathrm{M}$ of adriamycin. The ratio of alive vs. dead cells was computed (A/D ratio) and compared with that of adriamycin-free cultures as described previously $(14,15)$.

\section{Apoptosis on Simple Agarose Gel}

Apoptosis was assessed by the detection of DNA fragments (DNA ladders of multiples of 180 base pairs; bp) on simple agarose gel electrophoresis of total cellular DNA, as described previously $(14,15)$.

\section{Flow Cytometry}

The indexes of KLE cell cycle and apoptosis were assessed by flow cytometry analyzing DNA content in propidium iodide and HOECHST 33342-stained cells with a counter EPICS 753 pulse cytometer (Coulter Counter, Hialeah, FL). This technique permitted the calculation of the apoptotic cells, excluding necrotic cells (21). The KLE cells were exposed to $100 \mathrm{nM}$ of adriamycin for $48 \mathrm{hr}$. We analyzed apoptosis ( $\%$ of DNA content $<\mathrm{Gl}$ ) and computed the percentage of apoptotic cells and percent of phase distribution of KLE cells into the cell cycle, as described previously $(14,15)$.

\section{IGF-I Effects on KLE Cell Growth and Protection from Adriamycin Apoptosis}

We analyzed the ability of the optimal dose of IGF-I ( $50 \mathrm{ng} / \mathrm{mL}$ ) to protect KLE cells from adriamycin cytotoxicity. This was by calculating the number of dead (D) and alive (A) KLE cells, and by computing the A/D ratio using trypan blue exclusion. In addition, we analyzed the percent distribution of KLE cells at $<\mathrm{Gl}, \mathrm{Gl} / \mathrm{G} 0, \mathrm{~S}, \mathrm{G} 2 / \mathrm{M}$ phases in the cell cycle using flow cytometry. The optimal dose of IGF-1 was calculated by analyzing the dose-dependent effects of IGF-1 (1-100 ng/ml, final concentration) on the expected number and DNA content of KLE cells in vitro (14-16).

\section{Statistical Analysis}

The group means were assessed for statistical significance using one-tailed multiple comparison procedure of Dunnett's test only when treatments were compared with control values. When single comparisons were made, Student's test was used.

\section{Results}

IGF-1 Effects on the Proliferation of KLE Cells

IGF-1 produced a dose-dependent effect on the growth of KLE cells, as documented by the increasing number of alive KLE cells and increasing DNA content in KLE cell cultures (Fig. 1). The optimal dose of IGF-1 was $50 \mathrm{ng} / \mathrm{ml}$, which was capable of increasing by $35 \%$ the expected DNA content and number of KLE cells $(p<0.001)$. The expected DNA content and expected number of KLE cells were determined by parallel experiments in IGF-free cultures (controls) under identical experimental conditions. These data documented that IGF-1 exerted important mitogenic activity on KLE endometriallike cells.

\section{Adriamycin Cytotoxicity of KLE Cells by Trypan Blue}

The 48-hr exposure of KLE cells to $100 \mathrm{nM}$ (pharmacological dose) and $5 \mu \mathrm{M}$ (suprapharmacological dose) of adriamycin remarkably decreased $(p<0.001)$ the expected number of alive KLE cells grown with $0.5 \%, 2.5 \%$, and $5 \%$ CS (Fig. 2). The expected number of KLE cells was determined by parallel experiments in adriamycin-free cultures (controls). 

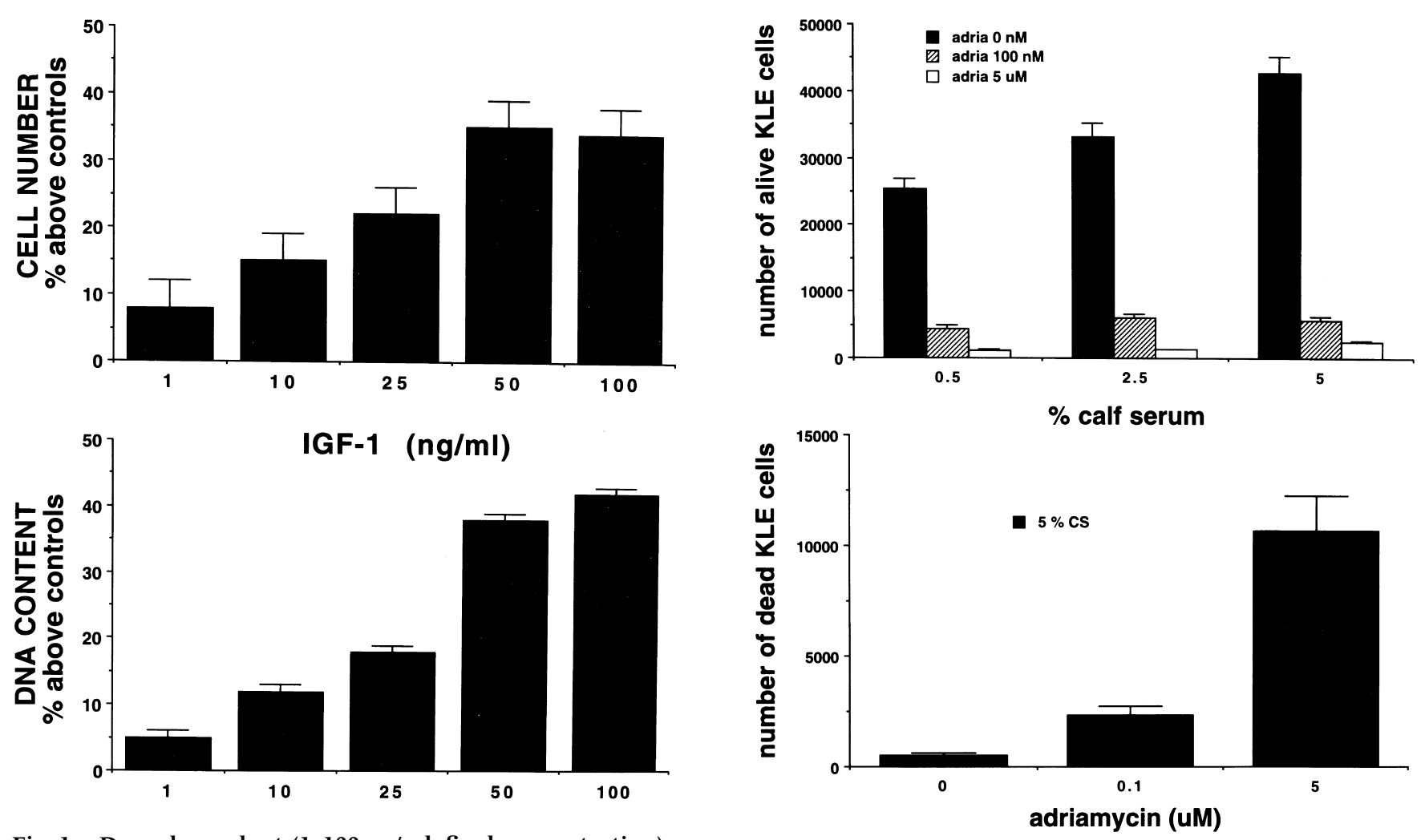

Fig. 1. Dose-dependent (1-100 ng/ml; final concentration) effect of insulin-like growth factor 1 (IGF-1) on KLE endometrial-like cells. (Upper panel) The effects of IGF-1 on DNA content of KLE cells. (Lower panel) The effects of IGF-1 on the number of KLE cells. KLE cells were growing in Dulbecco's modified Eagle's medium/F-12 (DMEM/F-12) containing 5\% calf serum (CS), as described in "Materials and Methods."

In addition, $2.5 \%$ and $5.0 \%$ CS remarkably increased $(p<0.001)$ the expected number of alive KLE cells, compared with KLE cultures containing $0.5 \%$ CS. Apparently, 5\% CS provided maximum stimulation for the growth of KLE cells in vitro (Fig. 2). Consequently, all future experiments were uniformly performed in DMEM/F-12 media containing 5.0\% CS. Increasing the concentration of CS did not modify the effects of $100 \mathrm{nM}$ and those of $5 \mu \mathrm{M}$ of adriamycin on the number of alive KLE cells (Fig. 2).

The expected number of dead KLE cells was increased significantly $(p<0.001)$ after 48 -hr exposure to pharmacological (100 $\mathrm{nM})$ and suprapharmacological doses $(5 \mu \mathrm{M})$ of adriamycin, as was calculated with trypan blue exclusion (Fig. 2). Because the analysis of adriamycin cytotoxicity must always consider the number of alive vs. dead cells in each cell culture (cytostasis probably decreases cytotoxicity), we also expressed our data as ratio of alive (A) vs. dead (D) KLE cells (A/D ratio). Indeed, adriamycin (48-hr exposure) decreased the expected A/D ratio from 81.0 in adriamycin-free/control KLE cell cultures to 2.4 (adriamycin $100 \mathrm{nM}$ ) and 0.2 (adriamycin $5 \mu \mathrm{M}$ ).

Fig. 2. The effects of adriamycin on KLE cells. KLE cells (100 $\mathrm{nM}$ and $5 \mu \mathrm{M}$; final concentration) were cultured with Dulbecco's modified Eagle's medium/F-12 (DMEM/F-12), containing $0.5 \%$ calf serum (CS), $2.5 \%$ CS and $5 \%$ CS, as described in "Materials and Methods. (Upper panel) The effects of adriamycin on the expected number of KLE cells. Note the dramatic decrease in the number of expected KLE cells in culture after $48 \mathrm{hr}$ incubation with adriamycin (100 nM and 5 $\mu \mathrm{M})$. Expected number of the KLE cells was determined in adriamycin-free (control) cell cultures. Increasing concentration of CS did not alter the adriamycin effects on KLE cells; whereas, $5 \%$ CS provided the optimum milieu for the growth of KLE cells in adriamycin-free cultures. (Lower panel) The dosedependent increase of the number of dead KLE cells after $48 \mathrm{hr}$ exposure to adriamycin ( $100 \mathrm{nM}$ and $5 \mu \mathrm{M})$ in media containing $5 \%$ CS, determined by trypan blue exclusion.

\section{Analysis of KLE Cell Cycle and Adriamycin Apoptosis by Flow Cytometry}

The phase distribution of KLE cells in the cell cycle and very few apoptotic ( $<\mathrm{Gl}=1 \%$ ) were documented by flow cytometry in adriamycin-free KLE cultures (Fig. 3). However, exposure to adriamycin (100 nM for $48 \mathrm{hr}$ ) produced a remarkable growth arrest of the KLE cells at G2/M phase, as suggested by the percent distribution of KLE cells in the cell cycle, which increased from $9.5 \%$ to $74.5 \%$. This was produced at the expenses of the percent distribution of KLE cells at G1/G0 and S phases, which decreased from $55.5 \%$ to $10 \%$, and from $35 \%$ to $15.5 \%$, respectively (Fig. 3 ). Moreover, adriamycin produced clear evidence of apoptosis (DNA fragmentation) of KLE cells, increasing the percent distribution at $<$ Gl from $1 \%$ to $29.5 \%$ 

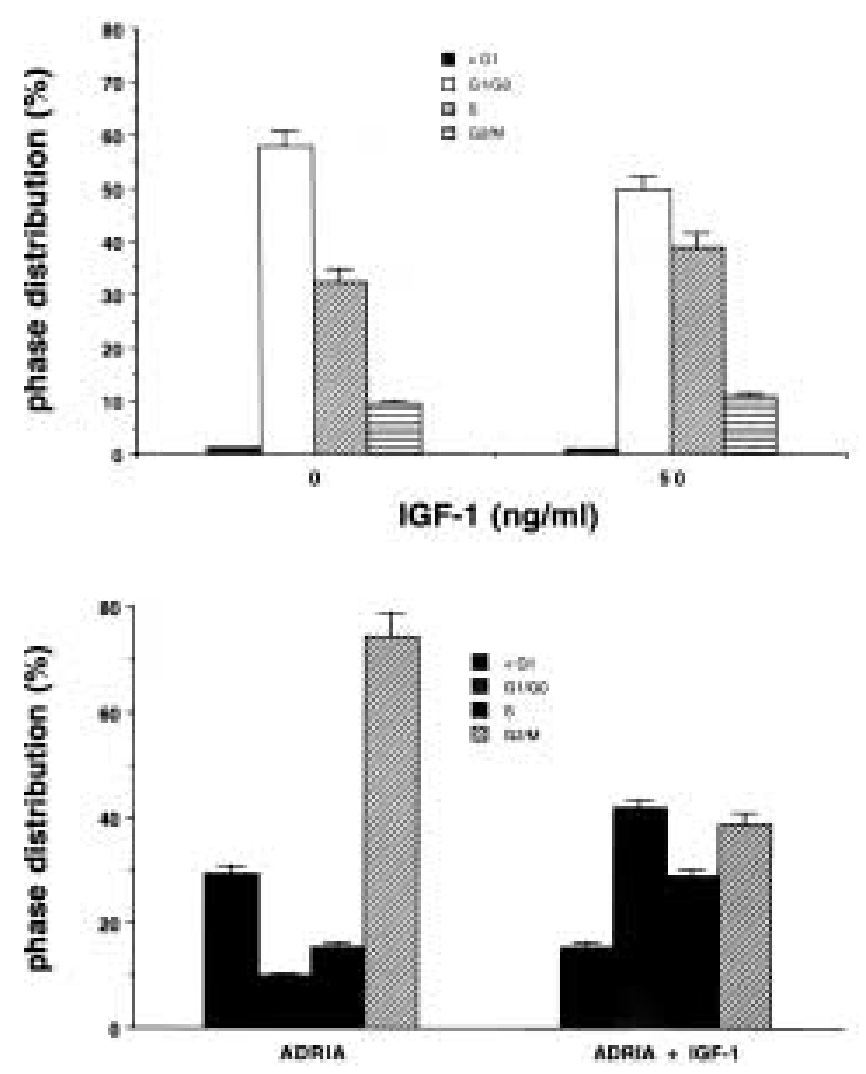

Fig. 3. Analysis of apoptosis and percent distribution of KLE cells in the cell cycle as determined by flow cytometry. (Upper panel) Insulin-like growth factor-1 (IGF-1; $50 \mathrm{ng} / \mathrm{ml}$ ) increased the percent distribution of KLE cells at the $S$ phase from $35 \% \pm 1.5$ of controls to $43.5 \% \pm 2$ of IGF-1treated KLE cells, mainly at the expenses of percent distribution of KLE cells at Gl/G0 phase (from $55.5 \% \pm 3$ of controls to $47 \% \pm 1.5$ of IGF-1-treated KLE cells). These data corroborated the mitogenic action of IGF-1 on KLE cells, described in the Fig. 1. Practically, there existed no apoptotic cells in control and IGF-1-treated KLE cells. (Lower panel) Adriamycin (100 nM) induced the apoptosis of KLE cells, as noted by the increased percent distribution of KLE cells at $<\mathrm{Gl}$ phase in the cell cycle, from $1.5 \% \pm 1$ of controls to $29.5 \pm$ $1.5 \%$ of adriamycin-treated KLE cells. In addition, adriamycin remarkably increased the percent distribution of KLE cells in the G2/M phase at the expenses of G1/G2 and S phases (G2/M phase increased from $9.5 \% \pm 2.2$ of controls to $74.5 \% \pm 3.0$ of adriamycin-treated KLE cells; whereas, Gl/G0 phase decreased from $55.5 \% \pm 3.0$ of controls to $10 \% \pm 2.0$ in adriamycintreated KLE cells and S phase decreased from $35 \% \pm 1.5$ in controls to $15.5 \% \pm 2.2$ of adriamycin-treated KLE cells $(p<$ $0.001)$. Therefore, adriamycin arrested KLE cells at G2/M phase and induced apoptosis of KLE cells. IGF-1 $(50 \mathrm{ng} / \mathrm{ml})$ decreased percent distribution at $\mathrm{G} 2 / \mathrm{M}$ phase by $50 \%$ and percent distribution at $<\mathrm{Gl}$ phase by $38 \%$ of adriamycintreated KLE cells $(p<0.001)$.

(Fig. 3). Most of the KLE cells exposed to $5 \mu \mathrm{M}$ of adriamycin for $48 \mathrm{hr}$ underwent apoptosis (75.0 \pm $5.0 \%$ of cells at $<\mathrm{Gl}$ ); whereas, the remaining few KLE cells in the cell cycle were distributed at the Gl/G0 and S phase and a few KLE cells were found at G2/M phase (data not shown).

\section{Analysis of DNA on Simple Agarose Gel}

Adriamycin (100 nM) apoptosis of KLE cells also was confirmed by the analysis of DNA on simple agarose gel, detecting the classic DNA ladders (multiple of 180 bp fragments) that accompanied programmed cell death in vitro (Fig. 4).

\section{IGF-1 Inhibition of Adriamycin Cytotoxicity}

The optimal dose of IGF- 1 as a growth factor on KLE cells $(50 \mathrm{ng} / \mathrm{ml})$ partially reversed the adriamycin (100 nM) effects on the cell cycle of KLE cells (Fig. 3). In addition, the optimal mitogenic dose of IGF-1 (50 ng/ml) partially protected KLE cells from adriamycin apoptosis (Fig. 3). Therefore, IGF-1 reversed both the adriamycin-induced cytostasis and adriamycin-induced apoptosis of KLE cells.

In concert with the above data, the optimal mitogenic dose $(50 \mathrm{ng} / \mathrm{ml})$ of IGF-1 also partially reversed the effects of adriamycin on the number of alive and dead KLE cells (Fig. 5). In addition, the A/D ratio of KLE cells increased from 2.4 (adriamycin $100 \mathrm{nM}$ ) to 31.0 (adriamycin plus IGF-1). Therefore, IGF-1 was a survival factor protecting KLE cells from adriamycin cytostasis and apoptosis.

\section{Discussion}

Regardless of which theory is the correct one for the pathogenesis of endometriosis: celomic metaplasia hypothesis, transplantation theory, or induction hypothesis $(1,2)$, development and evolution/progres-

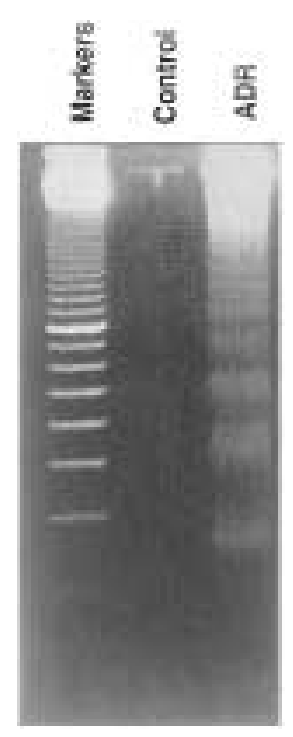

Fig. 4. Adriamycin (100 nM) induced the apoptosis of KLE cells. This was confirmed by the analysis of DNA fragmentation on simple agarose gel. Note the classic DNA ladders (multiple of $180 \mathrm{bp}$ fragments) that accompany programmed cell death in vitro. KLE cells were growing in Dulbecco's modified Eagle's medium/F-12 (DMEM/F-12) containing 5\% calf serum (CS) and apoptosis was triggered by the exposure to $100 \mathrm{nM}$ of adriamycin for $48 \mathrm{hr}$, as described in "Materials and Methods." 
sion of this disease is almost certainly associated with an abnormal immune function, altered peritoneal defense system, and bioactivity of growth substances in the endometrial-like tissue and PF $(3,22,23)$.

It currently is accepted that endometriosis is an entity of extreme pleiomorphism, which may include various and, in cases, overlapping pathogenetic pathways, including enviromental toxins (22-26). In addition, several growth substances of PF have been associated with the presence and severity of expression of endometriosis, including the uPA/IGFs/ IGFBP-3 bioregulation system, interleukins (ILs), transforming growth factor $\beta$ l (TGF $\beta 1)$, tumor necrosis factor $\alpha(\mathrm{TNF} \alpha)$, and vascular-endothelial growth factor (VEGF) (2-13,27-37).

Regarding the role of growth factors in the PF of women with endometriosis, particular interest has focused on the uPA-mediated production of N-terminal proteolytic fragments of IGFBP-3 $(3,5,6,10)$. Our laboratory also placed a lot of attention on the possible pivotal role of uPA in regulating the activity of several growth substances, such as the IGFs, in cancer metastases $(7,9,18)$ and PF $(4-6)$. In addition, other
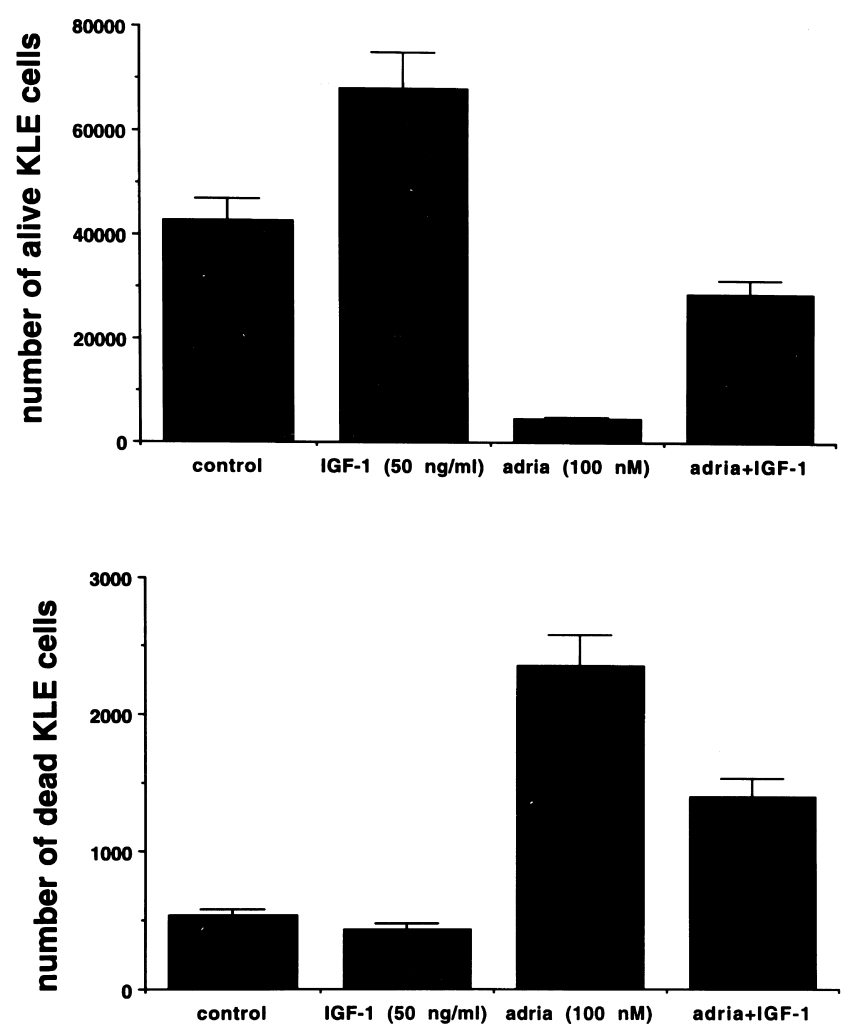

Fig. 5. Optimal concentration of Insulin-like growth factor-1 (IGF-1) partially reversed the adriamycin effects on (KLE) cells. (Upper panel) IGF-1 $(50 \mathrm{ng} / \mathrm{ml})$ acted as survival factor, reversing partially the adriamycin $(100 \mathrm{nM})$ reduction of expected number of KLE cells $(p<0.001)$. (Lower panel) IGF-1 $(50 \mathrm{ng} / \mathrm{ml})$ effects as a survival factor, reversed partially the adriamycin $(100 \mathrm{nM})$ increase of the expected number of dead KLE cells $(p<0.001)$. researchers have implicated the uPA/plasmin system and other matrix proteases in the pathophysiology of several reproductive tissues, including endometrium (38-40).

Because the pathogenesis of endometriosis possibly implicates the ectopic growth of endometriallike cells in the peritoneal cavity and it recently was reported that ectopic endometrial-like tissue presented with possible evidence of an altered apoptosis (41-44), we assessed whether an increased IGF-1 activity can protect endometrial-like cells from apoptosis. KLE is an endometrial cancer-derived cells that shares some characteristics of endometriallike cells $(4,45)$. Our study of the possible role of IGF- 1 as survival factor on KLE cells was proceeded by the characterization of adriamycin cytotoxicity of KLE cells. Under our experimental conditions, adriamycin (100 $\mathrm{nM}$ for $48 \mathrm{hr}$ ) produced the apoptosis of KLE endometrial-like cells and effectively arrested KLE cells at the G2/M phase in the cell cycle. Adriamycin cytotoxicity of KLE cells was neutralized partially by the exogenous IGF-1.

These data were in concert with recent findings that the exogenous administration of IGF-1 rescued breast and prostate cancer cells from programmed cell death in vitro $(14,15)$. Other, studies suggest that endogenous interleukin-6, which is known to be increased in the PF of women with endometriosis (29), is also a resistance factor for etoposide-mediated cytotoxicity of prostate cancer cells; whereas, IGF- 1 is a survival factor for PC- 12 cells $(46,47)$. The growth factor-mediated mechanism(s) of this rescue from apoptosis is unknown.

Recently, IGF-1 inhibition of the apoptosis of PC12 cells was associated with an increased expression of the $b c l$-xL gene product, suggesting that growth factors can regulate apoptosis-related genes acting as transcription factors (47). In addition, particular checkpoints were detected in apoptosis molecular pathways that met with the growth factor-signal transduction pathways (48). These checkpoints implicated serine phosphorylation-elimination of a death agonist $\mathrm{Bad}$ gene product as part of the response to survival factors $(48,49)$. Whether a similar mechanism is associated with the action of the IGF- 1 as "survival factors" on endometrial-like cells is currently under investigation in our laboratory.

In conclusion, several factors already have been characterized in the PF of women suffering from endometriosis for their mitogenic, angiogenic and immunosuppressive activity on endometrial-like cells. Our data suggest that the same autocrine/paracrine modulators of PF also may be implicated in optimizing the survival of endometrial-like cells in the peritoneal cavity. Herein, we document the role of IGF-1 as an important survival factor for endometrial- like cells in vitro. Conceivably, if these data hold to the in vivo situation, the protease(s)-mediated increase in IGF-1 activity can act similar to the survival growth factor for endometrial-like cells in the peri- 
toneal cavity of women with endometriosis. The later may suggest that pharmacologically targeting the survival factor activity of PF and endometriallike tissue can provide a novel therapeutic approach for the management of endometriosis.

\section{Acknowledgments}

Mr. P. Lembessis was given a student award and Prof. Michael Koutsilieris was awarded a research grant from the General Secretariat for Research and Technology, Ministry of Development, Government of Greece.

\section{References}

1. Bontis JN, Vavilis DT. (1997) Etiopathology of endometriosis. Ann. NY Acad. Sci. 816: 305-309.

2. Sharpe-Timms KL. (1997) Basic research in endometriosis. Object. Gynecol. Clin. N. Amer. 24: 2, 269-290.

3. Giudice LC. (1994) Growth factors and growth modulations in human uterine endometrium: their potential relevance to reproductive medicine. Fertil. Steril. 61: 1-17.

4. Koutsilieris M, Niklinski W, Frenette G, Lemay A. (1993) Heparin-sepharose binding growth factors in peritoneal fluid of women with endometriosis. Fertil. Steril. 59: 1, 93-97.

5. Koutsilieris M, Akoum A, Lazure C, Frenette G, Lemay A. (1995) N-terminal truncated forms of insulin-like growth factor binding protein-3 in the peritoneal fluid of women without laparoscopic evidence of endometriosis. Fertil. Steril. 63: 2, 314-321.

6. Koutsilieris M, Lavergne E, Lemay A. (1997) Association of protease activity against IGFBP-3 with peritoneal fluid mitogens: possible implications for the ectopic growth of endometrial cells in women with endometriosis. Anticancer Res. 17: 239-244.

7. Koutsilieris M, Frenette G, Lazure C. (1993) Urokinase-type plasminogen activator: a paracrine factor regulating the bioavailability of IGFs in PA-III cell-induced osteoblastic metastases. Anticancer Res. 13: 481-486.

8. Webber MM, Waghray A. (1995) Urokinase-mediated extracellutar matrix degradation and its inhibition by retinoid acid. Clin. Cancer Res. 1: 755-761.

9. Koutsilieris M, Polychronakos C. (1992) Proteolytic activity against IGF-binding proteins involved in paracrine interactions prostate adenocarcinoma cells and osteoblasts. Anticancer Res. 13: 481-486.

10. Giudice LC. (1995) IGF Binding protein-3 protease regulation: how sweet it is! J. Clin. Endocrinol. Metab. 80: 2279- 2280.

11. Muller HL, Youngman OH, Gargosky SE, Lehrnbecher T, Hintz RL, Rosenfeld RG. (1993) Concentrations of insulinlike growth factor (IGF)-binding protein-3 (IGFBP-3), IGF, and IGFBP-3 protease activity in cerebrospinal fluid of children with leukemia, central nervous system tumor, or meningitis. J. Clin. Endocrinol. Metab. 77: 1113-1119.

12. Matsumoto T, Gargosky SE, Iwasaki K, Rosenfeld RG. (1996) Identification and characterization of insulin-like growth factors (IGFs), IGF-binding proteins (IGFBPs), and IGFBP proteases in human synovial fluid. J. Clin. Endocrinol. Metab. 81: 150-155.

13. Lamson G, Giudice LC, Cohen P, Liu F, Gargosky S, Muller HL. (1996) Proteolysis of IGFBP-3 may be a common regulatory mechanism of IGF action in vivo. Growth Reg. 3: 91-95.

14. Reyes-Moreno C, Sourla A, Choki I, Doillon C, Koutsilieris M. (1998) Osteoblast-derived survival factors protect PC-3 human prostate cancer cells from adriamycin-apoptosis. Urology 52: 341-347.

15. Koutsilieris M, Reyes-Moreno C, Choki I, Sourla A, Doillon C, Pavlidis N. (1999) Chemotherapy cytotoxicity of human MCF-7 and MDA-MB 231 breast cells is altered by osteoblast-derived growth factors. Mol. Med. 5: 86-97.
16. Choki I, Sourla A, Reyes-Moreno C, Koutsilieris M. (1998) Osteoblast-derived growth factors enhance adrimycin-cytostasis of MCF-7 human breast cancer cells. Anticancer Res. 18: $4213-4224$.

17. Koutsilieris M, Tzanela M, Dimopoulos T. (1999) Novel concept of antisurvival factor (ASF). Therapy produces an objective clinical response on four patients with hormone-refractory prostate cancer: case report. Prostate 38: 313-316.

18. Koutsilieris M, Mitsiades CS, Sourla A. (2000) Insulin-like growth factor 1 and urokinase-type plasminogen activator bioregulation system as a survival mechanism of Prostate cancer cells in osteoblastic metastases: development of antisurvival factor therapy for hormone retractory Prostate cancer. Mol. Med. (In press).

19. Suganuma N, Harada M, Furuhashi M, Nawa A, Kikkawa F. (1997) Apoptosis in human endometrial and endometriotic tissues. Horm. Res. 48: 42-47.

20. Koutsilieris M, Mastrogamvrakis G, Miligos S, et al. (2000) Insulin-like growth factor 1 (IGF-1) is a survival factor protecting KLE endometrial-like cells from programmed cell death. In the program of the XIIth Biennial World Congress on Endometriosis: Endometriosis 2000, London, U.K.,

21. Darzynkiewicz Z, Bruno S, Delbiyo, G. (1992) Features of apoptotic cells measured by flow cytometry. Cytometry 13: 795-808.

22. Braun DP, Dmowski WP. (1998) Endometriosis. Curr. Opin. Obset. Gynecol. 10: 5, 365-369.

23. Leyendecker G. (2000) Redefining endometriosis: endometriosis is an entity with extreme pleiomorphism. Нum. Reprod. 15: 4-7.

24. Brosens IA, Brosens JJ. (2000) Endometriosis. Hum. Reprod. 15: $1-3$.

25. Zeyneloglu HB, Arici A, Olive DL. (1997) Environmental toxins and endometriosis. Obstet. Gynecol. Clin. N. Amer. 24: 2, 307-329.

26. Osteen KG, Sierra P, Rivera E. (1997) Does disruption of immune and endocrine systems by environmental toxins contribute to development of endometriosis? Semin. Reprod. Endocrinol. 15: 3, 301-308.

27. Akoum A, Doillon CJ, Koutsilieris M, et al. (1996) Human endometrial cells in a type I collagen gel. J. Reprod. Med. 41: 8, 555-561.

28. Pellicer A, Albert C, Mercader A, Bonilla-Musoles F, Remohí J, Simón C. (1998) The follicular and endocrine environment in women with endometriosis: local and systemic cytokine production. Fertil. Steril. 70: 3, 425-431.

29. Mahnke JL, Dawood MY, Huang JC. (2000) Vascular endothelial growth factor and interleukin-6 in peritoneal fluid of women with endometriosis. Fertil. Steril. 73: 166-170.

30. Bruner KL, Eisenberg E, Gorstein F, Osteen KG. (1999) Progesterone and transforming growth factor- $\beta$ coordinately regulate suppression of endometrial matrix metalloproteinases in a model of experimental endometriosis. Steroids 64: 648-653.

31. Arici A, Seli E, Zeyneloglu HB, Senturk LM, Oral E, Olive DL. (1998) Interleukin-8 induces proliferation of endometrial stromal cells: a potential autocrine growth factor. J. Clin. Endocrinol. Metab. 83: 4, 1201-1205.

32. Iwabe $T$, Harada $T$, Tsudo $T$, Tanikawa $M$, Onohara $Y$, Terakawa N. (1998) Pathogenetic significance of increased levels of interleukin-8 in the peritoneal fluid of patients with endometriosis. Fertil. Steril. 69: 924-930.

33. Akoum A, Lermay A, Lajeunesse $Y$, Marois M, Koutsilieris M. (1999) Immunohistochemical localization of insulin-like growth factor-binding protein-3 in eutopic and ectopic endometrial tissues. Fertil. Steril. 72: 1085-1092.

34. Sbracia M, Zupi E, Alo P, et al. (1997) Differential expression of IGF-I and IGF-II in eutopic and ectopic endometria of women with endometriosis and in women without endometriosis. Am. J. Reprod. Immunol. 37: 326-329.

35. Richer O, Mallmann, P, Van der Ven H, Krebs D. (1998) TNF$\alpha$ secretion by peritoneal macrophages in endometriosis. Zentralbl. Gynakol. 120: 7, 332-336. 
36. Smith SK. (1997) Angiogenesis. Semin. Reprod. Endocrinol. 15: 3, $221-227$.

37. Donnez J, Smoes P, Gillerot S, et al. (1998) Vascular endothelial growth factor (VEGF) in endometriosis. Hum. Reprod. 13: 6, 1686-1690.

38. Bruse C, Bergqvist A, Carlstróm K, (1998) Fibrinolytic factors in endometriotic tissue, endometrium, peritoneal fluid, and plasma from women with endometriosis and in endometrium and peritoneal fluid from healthy women. Fertil. Steril. 70: 5, 821-826.

39. Sharpe-Timms KL, Keisler LW, McIntush EW, Keisler DH. (1998) Tissue inhibitor of metalloproteinase- 1 concentrations are attenuated in peritoneal fluid and sera of women with endometriosis and restored in sera by gonadotropin-releasing hormone agonist therapy. Fertil. Steril. 69: 1128-1134.

40. Suzumori N, Sato M, Yoneda T, Ozaki Y, Takagi H, Suzumori K. (1999) Expression of secretory leukocyte protease inhibitor in women with endometriosis. Fertil. Steril. 72: 857-867.

41. Gebel HM, Braun DP, Tambur A, Frame D, Rana N, Dmowski WP. (1998) Spontaneous apoptosis of endometrial tissue is impaired in women with endometriosis. Fertil. Steril. 69: 6, 1042-1047.

42. McLaren J, Prentice A, Charnock P, et al. (1997) Immunolocalization of the apoptosis regulating proteins $\mathrm{Bcl}-2$ and Bax in human endometrium and isolated peritoneal fluid macrophages in enodmetriosis. Hum. Reprod. 12: 1, 146-152.
43. Watanabe H, Kanzaki H, Narukawa S, et al. (1997) Bcl-2 and Fas expression in eutopic and ectopic human endometrium during the menstrual cycle in relation to endometrial cell apoptosis. Am. J. Obstet. Gynecol. 176: 2, 360-368.

44. Braun DP, Gebel H, Rana N, Dmowski WP. (1998) Cytolysis of eutopic and ectopic endometrial cells by peripheral blood monocytes and peritoneal macrophages in women with endometriosis. Fertil. Steril. 69: 1103-1108.

45. Hendricks DT, Taylor R, Reed M, Binner MJ. (1997) FHIT gene expression in human ovarian, endometrial, and cervical cancer cell lines. Cancer Res. 57: 2112-2115.

46. Borsellino N, Belldegrun A, Bonavida B. (1995) Endogenous interleukin 6 is a resistance factor for cisdiamminedichloroplatinum and etoposide-mediated cytotoxicity of human Prostate carcinoma cell lines. Cancer Res. 55: 4633-4639.

47. Parrizas M, LeRoith D. (1997) Insulin-like growth factor-1 inhibition of apoptosis is associated with increased expression of the bcl-x gene product. Endocrinology 138: 13551358.

48. Gajewski TF, Thompson CB. (1996) Apoptosis meets signal tranduction: elimination of a BAD influence. Cell 86: 589-592.

49. Zha J, Harada H, Yang E. (1996) Serine phosphorylation of death agoinst Bad in response to survival factor results in binding to 14-3-3 not Bcl-XL. Cell 87: 619-628. 